\title{
The effect of vesicular-arbuscular mycorrhizal inoculation on the growth and root colonization of ten strawberry cultivars
}

\begin{abstract}
MAURITZ Vestberg
VESTBERG, M. 1992. The effect of vesicular-arbuscular mycorrhizal inoculation on the growth and root colonization of ten strawberry cultivars. Agric. Sci. Finl. 1: 527-535. (Agric. Res. Centre of Finland, Laukaa Res. and Elite Plant Unit, SF-41340 Laukaa, Finland.)

Ten strawberry cultivars, four early maturing, three late maturing and three "special" cultivars, were inoculated with six strains of vesicular-arbuscular mycorrhizal (VAM) fungi in a pot experiment. Growth effects and colonization of the VAM fungi were studied. Three strains, Glomus macrocarpum V3, G. mosseae Rothamsted and G. sp. $\mathrm{V} 4$, were highly efficient, causing significant growth increases in most cultivars. 'Jonsok' showed the highest mycorrhizal dependency index, 648, and 'Ostara' the lowest, 269, for the mean response of all six fungi. The fungal strains which increased shoot growth the most also increased the runner plant formation the most. Early cultivars showed higher colonization percentages than late maturing cultivars. Sporulation of the introduced VAM fungi was on average more abundant in early and special cultivars than in late cultivars. Root colonization and strawberry shoot dry weight correlated significantly in most cultivars, but the correlation between colonization and runner formation was generally poor.
\end{abstract}

Key words: VAM, strawberry cultivar, growth response, colonization, mycorrhizal dependency

\section{Introduction}

The variation in response of different plant species to vesicular-arbuscular mycorrhizal (VAM) infection is well documented (Powell 1986). Differences in response to mycorrhizal infection is also observed among cultivars, for example in pea (EsTAUN et al. 1987), wheat (BERTHEAU et al. 1980, STÖPPLER et al. 1990, VIERHEILIG and OCAMPO 1991), peach (TRAQUAIR and BERCH 1988) and apple rootstocks (GRANGER et al. 1983), maize (HALl 1978, TотH et al. 1990), cowpea
(RAJAPAKSE and Miller 1988), peanut (DAFT 1991) and sorghum (RAJU et al. 1990). BRYLA and KOIDE (1990) studied the role of mycorrhizal infection in the growth and reproduction of wild accessions and cultivars of tomato.

In strawberry, the cultivar effect was studied by ROBERTSON et al. (1988), who found first-year greenhouse plants of strawberry always to be nonmycorrhizal, but colonization of plants growing in fumigated foundation (2nd year) and certified fields (3rd year) to be highly variable between cultivars. However, in a glasshouse trial, all strawberry culti- 
vars were infected equally (ROBERTSON et al. 1988). In Mexico, CHAVEZ and FERRERA-CERRATO (1990) observed differences in strawberry cultivar responses to VAM fungal colonization.

The objective of this study was to determine the effect of six VAM strains on ten strawberry cultivars commercially grown in Finland. Differences in response between early maturing, late maturing and special cultivars were also evaluated. The experiment was carried out in a glasshouse.

\section{Material and methods}

\section{Cultivars}

Ten cultivars were studied. Eight of these belonged to the species Fragaria $\times$ ananassa Duch. One cultivar was a $F$. virginiana Duch. hybride ('Alaska Pioneer') and one cultivar was a $F$. vesca L. ('Minja'). With respect to maturity they were divided into early, late and "special" cultivars. 'Jonsok', 'Zefyr', 'Kristina' and 'Mari' were early cultivars. The cultivars 'Bounty', 'Hiku' and 'Senga Sengana' were regarded as late cultivars for Finnish growing conditions. The special cultivars studied were the everbearer 'Ostara', as well as 'Alaska Pioneer' and 'Minja'.

\section{Inoculum}

The inocula were produced by growing the VA-mycorrhizal fungi in maize (F1 hybrid 'North Star') roots for 103 days, from 24 April to 7 August, 1989, in a glasshouse. A steam sterilized (three times on successive days) sand was used as growth substrate for the inoculum. The substrate was limed to give a $\mathrm{pH}$ of approx 6.0, and fertilized with $2 \mathrm{~g} \mathrm{l}^{-1}$ bone meal (DAFT and NiCOLSON 1966). Phosphorus-free Hewitt solution was applied once a week. The inocula, a mixture of infected maize root pieces with adhering sand, hyphae and spores were left to dry and stored at $+6^{\circ} \mathrm{C}$ until use. The strains and their origin, the number of spores and the percentage of root infection were as follows:

\begin{tabular}{|c|c|c|c|}
\hline \multicolumn{2}{|c|}{ Strain } & \multicolumn{2}{|c|}{ Inoculum } \\
\hline Name & Origin & VAM- $\%$ & res/g \\
\hline $\begin{array}{l}\text { 1. Glomus mossae, } \\
\text { Rothamsted }\end{array}$ & Kent, UK & 4 & 126 \\
\hline $\begin{array}{l}\text { 2. Glomus sp. V4, } \\
\text { "thin-walled white" }\end{array}$ & Kärsämăki, FIN & 48 & 1 \\
\hline $\begin{array}{l}\text { 3. G. macrocarpum } \\
\text { V3 }\end{array}$ & Saarijärvi, FIN & 30 & $<1$ \\
\hline 4. $G$. intraradices $V$ & Anjala, FIN & 27 & $<1$ \\
\hline $\begin{array}{l}\text { 5. G. sp. V21/88, } \\
\text { "thin-walled white" }\end{array}$ & $\begin{array}{l}\text { Pelkosenniemi, } \\
\text { FIN }\end{array}$ & 49 & 9 \\
\hline 6. G. mosseae V11b & Nilsiä, FIN & $<1$ & 38 \\
\hline
\end{tabular}

\section{Experiment}

The experiment was started in a glasshouse on 27 and 28 May, 1990, and it lasted 91 days. The growth substrate was a steam sterilized ( $1 \mathrm{~h}$ on three successive days) sand basically limed with $5 \mathrm{~g} \mathrm{l}^{-1}$ dolomite lime to $\mathrm{pH} 6$, and fertilized with $2 \mathrm{~g} \mathrm{l}^{-1}$ bone meal (DAFT and NiCOLSON 1966). The substrate was stored open for at least two weeks after the steam sterilization. Micropropagated strawberry plantlets were planted in $2.5 \mathrm{dl}$ plastic Vefi pots. The inoculum, ( $1 \mathrm{ml}$ for each plant) which had been stored for 10 months, was placed into the planting hole prior to planting. After planting the pots were placed on top of an approx. $2 \mathrm{~cm}$ layer of wet vermiculite. During the experiment, the vermiculite substrate was watered and a phosphorus-free $\mathrm{He}$ witt solution $(0.1 \%)$ was applied. The experiment was of a split-plot design. During the experiment, the temperature in the glasshouse varied between $+20^{\circ} \mathrm{C}$ and $+39^{\circ} \mathrm{C}$.

\section{Observations}

Growth response at the end of the experiment was evaluated by the following criteria:

- shoot dry weight including mother plant and runners

- number of runners/mother plant

- number of runner plants/mother plant 
Mycorrhizal dependency (MD) of strawberry cultivars was determined as the ratio of dry weight of inoculated plants to uninoculated plants multiplied by 100 . The percentage of infected root was determined by the gridline intersect method (GIOVANNETTI \& MOSSE 1980). The abundance of spores in strawberry pots was estimated from a 50 $\mathrm{ml}$ root and soil sample. The sample was washed through a 0.5 and a $0.074 \mathrm{~mm}$ sieve and the amount of spores detected on the sieves was evaluated on a rating scale of $0-5$ as follows:

$0=$ no spores

$1=$ very few spores $(1-5 / 50 \mathrm{ml}$ substrate $)$

$2=$ few spores $(6-20 / 50 \mathrm{ml}$ substrate $)$

$3=$ a moderate number of spores (20-several hundreds $/ 50 \mathrm{ml}$ substrate)

$4=$ spores abundantly

$5=$ spores very abundantly

\section{Results}

\section{Shoot growth}

Significant growth responses due to VAM inoculation were observed in all cultivars (Fig. 1). Three strains, G. macrocarpum V3 (3), G. mosseae (1) Rothamsted and $G$. sp. V4 (2), were on average superior to the rest of the strains. G. macrocarpum V3 (3) increased shoot dry weight the most in all cultivars.

In 'Minja', all isolates used caused a significant growth increase. In 'Senga Sengana' and 'Mari', only two out of six strains increased growth significantly. The rest of the cultivars lay between these extremes (Fig. 1).

The group of the three less efficient strains tended to stimulate the growth of special cultivars in particular. G. intraradices V20 (4) increased growth significantly in all the special cultivars, in one of the late cultivars ('Hiku') but in none of the early cultivars. Glomus sp. V21/88 (5) increased growth significantly only in the early cultivar 'Kristina' and in the special cultivar 'Minja', while G. mosseae (6)
V11b did so in the early cultivar 'Jonsok', and in all the special cultivars (Fig. 1).

'Jonsok' had the highest mycorrhizal dependency index (MD), 648, and 'Ostara' the lowest MD, 269, for the mean response of all six fungi. When $\mathrm{MD}$ was calculated for the most efficient strain, G. macrocarpum V3 (3), it varied from 920 in 'Hiku' to 366 in 'Mari'. When the least efficient VAM strain was used, the MD varied from 400 in 'Kristina' to 138 in 'Hiku' and 'Ostara' (Table 1).

Table 1. Mycorrhizal dependency of ten strawberry cultivars.

\begin{tabular}{|c|c|c|c|c|}
\hline \multirow[b]{2}{*}{ Cultivar } & & \multicolumn{3}{|c|}{ Mycorrhizal dependency (MD) } \\
\hline & & $\begin{array}{l}\text { Most } \\
\text { efficient } \\
\text { strain }\end{array}$ & $\begin{array}{l}\text { Least } \\
\text { efficient } \\
\text { strain }\end{array}$ & $\begin{array}{l}\text { Average of } \\
6 \text { strains }\end{array}$ \\
\hline \multicolumn{5}{|l|}{ Early } \\
\hline & 'Jonsok' & 829 & 373 & 648 \\
\hline & 'Zefyr' & 522 & 229 & 358 \\
\hline & 'Kristina' & 614 & 400 & 470 \\
\hline & 'Mari' & 366 & 196 & 281 \\
\hline \multicolumn{5}{|l|}{ Late } \\
\hline & 'Hiku' & 920 & 138 & 626 \\
\hline & 'Senga Sengana' & 414 & 278 & 309 \\
\hline & 'Bounty' & 618 & 200 & 471 \\
\hline \multicolumn{5}{|l|}{ Special } \\
\hline & 'Ostara' & 319 & 138 & 269 \\
\hline & 'Alaska Pioneer' & 757 & 294 & 553 \\
\hline & 'Minja' & 475 & 252 & 278 \\
\hline
\end{tabular}

\section{Runner formation}

With regard to runner plant production the strawberry cultivars used in the experiment could be divided into three groups. The cultivars 'Hiku', 'Mari', 'Bounty' and 'Kristina' produced only a minimum amount of runner plants during the experimental period. 'Senga Sengana', 'Zefyr', 'Jonsok', 'Ostara' and 'Alaskan Pioneer' produced à moderate number of runner plants, while 'Minja' produced runner plants abundantly. The results of 'Minja' only are presented here.

In 'Minja', the three strains (G. macrocarpum V3 (3), G. mosseae Rothamsted (1) and G. sp. V4 (2) ) 


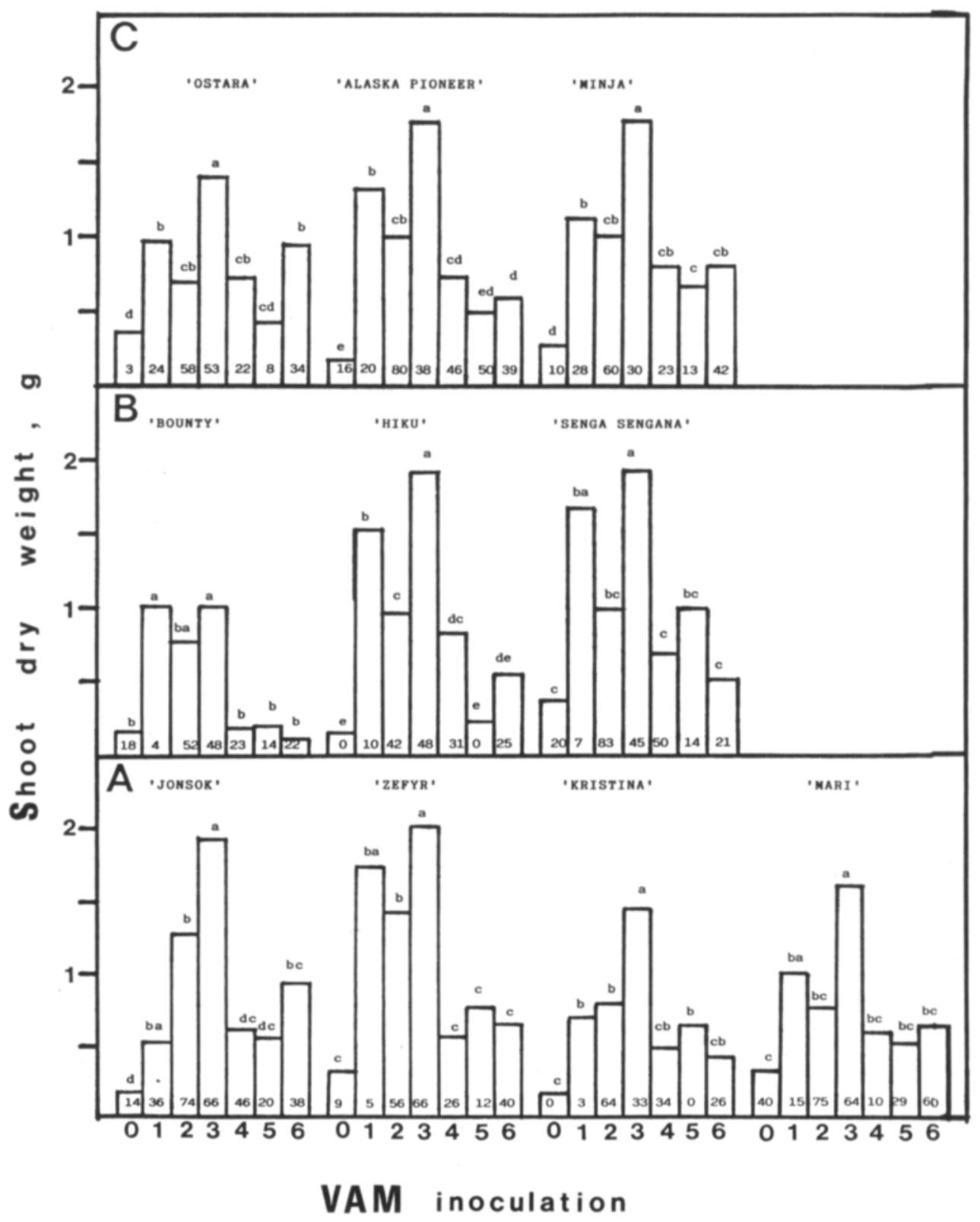

Fig. 1. The effect of VAM inoculation on shoot dry weight and root colonization of ten strawberry cultivars. Pot experiment in the glasshouse. Early maturing, late maturing and "special" cultivars are indicated by letters A, B and C, respectively. For inoculation treatments $(0=$ uninoculated, $1-6=$ inoculated $)$ see material and methods. Numbers inside bars indicate root colonization percentages. Within cultivars, bars of shoot dry weights marked with different letters differ significantly at $\mathbf{P}=0.05$. 


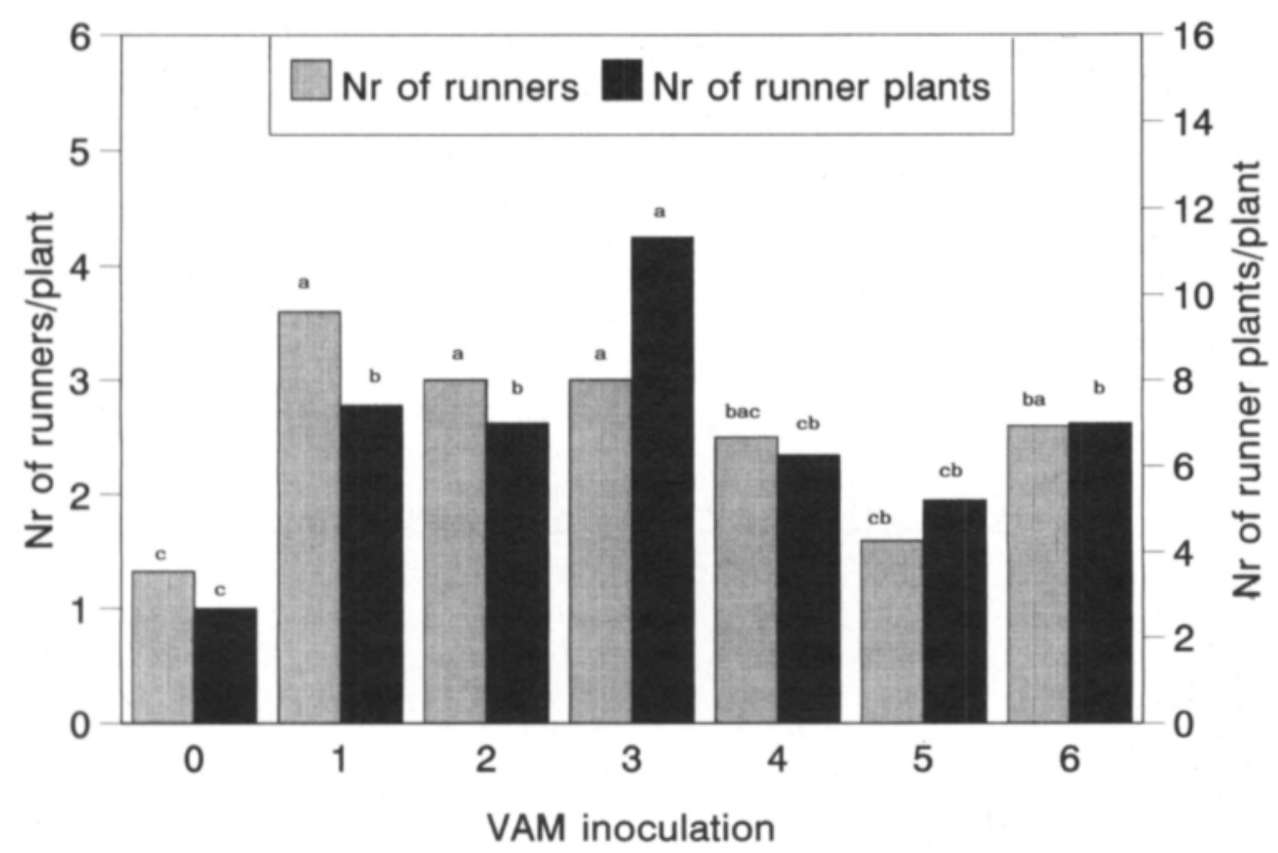

Fig. 2. The effect of VAM inoculation on the number of runners and the number of runner plants per mother plant in cultivar Minja. Pot experiment in the glasshouse. For inoculation treatments $(0=$ uninoculated, $1-6=$ inoculated), see material and methods. Bars of runners and number of runner plants, respectively, marked with different letters differ significantly at $\mathrm{P}=0.05$.

which caused the highest shoot growth increase, increased significantly also the numbers of runners and numbers of runner plants per mother plant (Fig. 2). However, also G. mosseae V11b (6) increased significantly runner and runner plant production.

\section{Root colonization and sporulation}

All cultivars tested showed mycorrhizal colonization. Only in two host-fungus combinations, i.e. for strain V21/88 (5) in 'Kristina' and 'Hiku', no root colonization occurred (Fig. 1). G.sp. V4 (2) caused the highest root infection, which varied from $42 \%$ in 'Hiku' to $83 \%$ in 'Senga Sengana'. The early cultivars had on average a higher colonization percentage than the late cultivars (Fig. 1, Table 2). 'Mari' and 'Jonsok', both early cultivars, had on average (of 6 VAM isolates) the highest root infection levels, $42.44 \%$ and $42.09 \%$, respectively. 'Hiku', a late cultivar, had the lowest average VAM infection, $22.71 \%$. Of the special cultivars, 'Alaska Pioneer' had also a high average root infection which exceeded $40 \%$. Due to a spread of VAM fungi, uninoculated plants were also infected in many instances.

Out of six VAM strains, four sporulated under the prevailing conditions. The G. mosseae strain from Rothamsted (1) sporulated in all cultivars and $G$. macrocarpum (3) sporulated in all cultivars but 'Senga Sengana' and 'Minja'. The highest average sporulation was found in 'Mari' and 'Alaska pioneer'. The average sporulation index was higher in the early maturing $(0.88)$ and special $(0.78)$ than in the late maturing $(0.50)$ cultivars (Table 2$)$.

\section{Correlations}

The strawberry shoot dry weights correlated significantly with VAM colonization in many cultivars (Table 3). A high correlation was found in the cul- 
Table 2. The effect of VAM inoculation on root colonization and sporulation of ten strawberry cultivars as an average of six VAM isolates. Colonization percentages followed by different letters differ significantly at $\mathbf{P}=0.05$.

\begin{tabular}{|c|c|c|c|}
\hline \multirow{2}{*}{\multicolumn{2}{|c|}{ Strawberry cultivar }} & \multicolumn{2}{|c|}{ Mean of 6 VAM isolates } \\
\hline & & $\begin{array}{l}\text { Root } \\
\text { colonization, \% }\end{array}$ & $\begin{array}{c}\text { Sporulation } \\
0-5\end{array}$ \\
\hline \multicolumn{4}{|l|}{ Early } \\
\hline & 'Jonsok & $42.09^{\mathrm{a}}$ & 0.75 \\
\hline & 'Zefyr' & $31.38^{\mathrm{ba}}$ & 0.83 \\
\hline & 'Kristina' & $22.97^{b}$ & 0.75 \\
\hline & 'Mari' & $42.44^{\mathrm{a}}$ & 1.17 \\
\hline \multicolumn{4}{|l|}{ Late } \\
\hline & 'Hiku' & $22.71^{\mathrm{b}}$ & 0.42 \\
\hline & 'Senga Sengana' & $34.86^{\text {ba }}$ & 0.50 \\
\hline & 'Bounty' & $26.12^{b}$ & 0.58 \\
\hline \multicolumn{4}{|c|}{ Special } \\
\hline & 'Ostara' & $27.97^{b}$ & 0.58 \\
\hline & 'Alaska Pioneer' & $41.13^{\mathrm{a}}$ & 1.17 \\
\hline & 'Minja' & $30.90^{\text {ba }}$ & 0.58 \\
\hline
\end{tabular}

Table 3. Significance of correlation coefficients (r) of linear plots between percentage root colonization and shoot dry weight, the number of runners/mother plant and number of runner plants/mother plant in 10 strawberry cultivars. $\mathrm{N}=$ $35 /$ cultivar. NS $=$ not significant. ${ }^{*}, * *$, and $* * *$ indicate significances at the $10 \%, 5 \%$ and $1 \%$ levels, respectively.

\begin{tabular}{|c|c|c|c|c|}
\hline \multirow[b]{2}{*}{ Cultivar } & \multicolumn{4}{|c|}{ Correlation between root colonization and } \\
\hline & & $\begin{array}{l}\text { Shoot } \\
\text { dry } \\
\text { weight }\end{array}$ & $\begin{array}{l}\text { Number } \\
\text { of } \\
\text { runners/ } \\
\text { plant }\end{array}$ & $\begin{array}{l}\text { Number of } \\
\text { runner } \\
\text { plants/ } \\
\text { plant }\end{array}$ \\
\hline \multicolumn{5}{|l|}{ Early } \\
\hline & 'Jonsok' & $* * *$ & NS & $* *$ \\
\hline & 'Zefyr' & $* *$ & $* * *$ & $* *$ \\
\hline & 'Kristina' & $* * *$ & NS & NS \\
\hline & 'Mari' & $*$ & NS & NS \\
\hline \multicolumn{5}{|l|}{ Late } \\
\hline & 'Hiku' & $* * *$ & NS & NS \\
\hline & 'Senga Sengana' & NS & NS & NS \\
\hline & 'Bounty' & * & NS & NS \\
\hline \multicolumn{5}{|l|}{ Special } \\
\hline & 'Ostara' & $* * *$ & * & $*$ \\
\hline & 'Alaska Pioneer' & NS & NS & NS \\
\hline & 'Minja' & $* *$ & $* * *$ & NS \\
\hline
\end{tabular}

tivars 'Jonsok', 'Hiku', 'Ostara' and 'Kristina', a moderate correlation in the cultivars 'Zephyr' and 'Minja', a weak correlation in the cultivars 'Mari' and 'Bounty', and no correlation in 'Senga Sengana' and 'Alaskan Pioneer'. In contrast to this, runner formation and root colonization correlated only occasionally in a few cultivars. The numbers of runners per plant correlated significantly with VAM colonization in 'Zefyr' and 'Minja', and the number of runner plants per mother plant did so in 'Zefyr' and 'Jonsok'.

\section{Discussion}

Differences in response of cultivars to VAM inoculation have been demonstrated in numerous studies. In extreme instances, cultivars within one plant species may response to VAM inoculation in varying degrees, from highly increasing to decreasing response (BERTHEAU et al. 1980). Plant species which are normally mycorrhizal have even been made non-mycorrhizal by mutation (Duc et al. 1989). However, lack of differences in cultivar response to VAM inoculation has also been reported (GRANGer et al. 1983, TraquaIR \& BerCH 1988).

In the present study, all Finnish commercial strawberry cultivars responded positively to VAM inoculation during the prevailing experimental conditions in the glasshouse. However, there were differences in response to fungal strains, which stresses the importance of screening for mycorrhizal efficiency in VAM research. Of six strains, three were highly efficient, causing significant growth responses rather uniformly in all the cultiv-ars. However, a group of three other strains were less efficient, which resulted in different patterns of response in the cultivars. This group of strains tended to increase shoot growth of strawberry the most in the special cultivars, including the semi-wild 'Alaska Pioneer' and 'Minja' cultivars. This indicates a difference in response in wild or semi-wild vs cultivated genotypes of strawberry to VAM infection. Such differences in response have been found also by KoIDE et al.(1988) and BRYLA and KOIDE 
(1990) in oats and tomato. However, contrary to our study, they found that the cultivars were as a group more responsive to mycorrhizal infection than the wild accessions.

Mycorrhizal dependency (MD) is used as an index to compare the receptivity of different plant species or cultivars to VAM fungi (GERDEMANN 1975). The MD can vary from none to complete dependency. However, the MD of a host can be altered by a number of factors such as soil type, soil phosphorus content, mycorrhizal species, etc. (MENGE et al. 1978, AZCON \& OCAMPO 1981). This was also demonstrated in the present study, where the MD index for strawberry cultivars varied considerably when calculated for the most or for the least efficient VAM strain. The MD of the cultivars varied from 648 in 'Jonsok' to 281 in 'Mari', but no distinct differences were observed between early, late or special cultivars when the MD was calculated as an average for all six VAM strains. It can be concluded that all strawberry cultivars tested show a moderate mycorrhizal dependency under lowphosphorus conditions.

A number of studies have been conducted to find out the reasons for differences in MD at the cultivar level. BAYLIS (1975) reported that the length of root hairs and the thickness of roots can determine the MD level of a plant species or cultivar. MENGE et al. (1978) suggested that the number of feeder roots in citrus cultivars might correlate with MD. In another study with citrus, GRAHAM and SYVERTSEN (1985) showed that the leaf P concentration, fineness of roots, growth rate, hydraulic conductivity, transpiration and $\mathrm{CO}_{2}$ assimilation rate were linked to MD. In cowpea, RAJAPAKSE and MILLER
(1988) observed that the average length of fine roots was negatively correlated with $\mathrm{MD}$. However, only $27 \%$ of the variability in MD was explained by this variable. Therefore, they conclude that root morphology did not appear to determine the MD in cowpea.

Early strawberry cultivars showed on average a higher root colonization and sporulation than late cultivars. The reason for this remains unknown, because no root growth parameters were determined in the present study. However, it is a wellknown fact that cultivars differ from each other with respect to root morphology. Also root exudation has been found to vary greatly between cultivars. AZCON and OCAMPO (1981) found that the absence of mycorrhizal infection in some wheat varieties was associated with lack of sugar exudation from the roots rather than with the sugar content of the roots. In their study, VA infection led to a decrease in the reducing and total sugar content of root extracts, and this effect correlated with the degree of mycorrhizal infection.

The results of this study cannot be directly extrapolated to field conditions, where a much more complex system of microorganisms, indigenous VAM fungi, nutrients and soil animals prevails. However, in strawberry fields of low soluble P and low incidence of indigenous VAM fungi (such fields do occur), strawberry cultivars can be expected to react to inoculation by different arbuscular mycorrhizal fungi in a similar manner to that of the present pot experiment. In conclusion, however, the cultivar response to mycorrhization under field conditions needs further study.

\section{References}

Azcon, R \& OCAmPo, J.A. 1981. Factors affecting the vesicular-arbuscular infection and mycorrhizal dependency of thirteen wheat cultivars. N. Phytol. 87: 677-685.

BAYLIS, G.T.S. 1975. The magnoloid mycorrhiza and mycotrophy in root systems derived from it. In: Sanders, F.E. et al. (eds.). Endomycorrhizas. Academic Press. London.
Bertheau, Y, Gianinazzi-Pearson, V. \& Gianinazzi, S. 1980. Developpement et expression l'association endomycorhizienne chez le ele. I. Mise en evidence d'un effet varietal. Ann. Amelior. Pl. 30: 67-78.

BRYLA, D.R. \& KoIDE, R.T. 1990. Regulation of reproduction in wild and cultivated Lycopersicon esculentum Mill. by 
vesicular-arbuscular mycorrhizal infection. Oecologia 84: 74-81.

- 1990. Role of mycorrhizal infection in the growth and reproduction of wild vs. cultivated plants. II. Eight wild successions and two cultivars of Lycopersicon esculentum Mill. Oecologia 84: 82-92.

Chavez, MC.G. \& Ferrera-Cerrato, R. 1990. Effect of Vesicular-Arbuscular Mycorrhizae on Tissue Culturederived Plantlets of Strawberry. HortSci. 25: 903-905.

DAFT, M.J. 1991. Influences of genotypes, rock phosphate and plant densities on mycorrhizal development and the growth responses of five different crops. Agric. Ecosyst. Environm. 35: 151-169.

— \& Nicolson, T.H. 1966. Effects of Endogone mycorrhizae on plant growth. New Phytol. 65: 343-350.

Duc, G., Trouvelot, A., Gianinazzi-Pearson, V. \& GianiNAZZI, S. 1989. First report of non-mycorrhizal plant mutants (Myc) obtained in pea (Pisum sativum L.) and fababean (Vicia faba L.). Pl. Sci. 60: 215-222.

Estaun, V., Calvet, C. \& Hayman, D.S. 1987. Influence of plant genotype on mycorrhizal infection: Response of three pea cultivars. Pl. Soil 103: 295-298.

GERDEMANN, J.W. 1975. Vesicular-arbuscular mycorrhizae. In: Torrey, J.G. \& Clarkson, D.T. (eds.). The development and function of roots. Academic Press. London. $618 \mathrm{p}$.

Giovannetti, M. \& Mosse, B. 1980. An evaluation of techniques for measuring vesicular-arbuscular mycorrhizal infection in roots. New Phytol. 84: 489-500.

Graham, J.H. \& SYVERTSEN, J.P. 1985. Host determinants of mycorrhizal dependency of citrus rootstock seedlings. New Phytol. 101: 667-676.

Granger, R.L., Plenchette, C. \& Fortin, J.A. 1983. Effect of a vesicular-arbuscular (VA) endomycorrhizal fungus (Glomus epigaeum) on the growth and leaf mineral content of two apple clones propagated in vitro. Can. J. Pl. Sci. 63: 551-555.

HALL, J.R. 1978. Effect of vesicular-arbuscular mycorrhizas on two varieties of maize and one of sweetcorn. N.Z. J. Agric. Res. 21: 517-519.

KoIDE, R.T., LI, M.,LewIS, J. \& IRBY, C. 1988. Role of mycorrhizal infection in the growth and reproduction of wild vs. cultivated plants. I. Wild vs. cultivated oats. Oecologia 77: 537-543.

Menge, J.A., Johnson, E.L.V. \& Platt, R.G. 1978. Mycorrhizal dependency of several citrus cultivars under three nutrient regimes. New Phytol. 81: 553-559.

PowELL, C.L. 1986. Field inoculation with VA mycorrhizal fungi. In: Powell, C.L. \& Bagyaraj, D.J. VA-mycorrhiza. CRC Press Inc. Boca Raton, Florida. 234 p.

RAJAPAKSE, S. \& MiLler,JR. J.C. 1988. Relationship between cowpea root systems and mycorrhizal dependency. HortSci. 23: 568-570.

Ravu, P.S., Clark, R.B., Ellis, J.R., Duncan, R.R. \& MaRANVILLE, J.W. 1990. Benefit and cost analysis and phosphorus efficiency of VA mycorrhizal fungi colonizations with sorghum (Sorghum bicolor) genotypes grown at varied phosphorus levels. Pl. Soil 124: 199-204.

Robertson, W.J., Boyle, C.D. \& Brown, H.L. 1988. Endomycorrhizal status of Certified Strawberry Stock. J. Am. Soc. Hort. Sci. 113: 525-529.

Stôppler, H., Kólsch, E. \& Vogtmann, H. 1990. Vesiculararbuscular Mycorrhiza in Varieties of Winter Wheat in a Low External Input System. Biol. Agric. \& Hort. 7: 191-199.

Toth, R., Toth, D., Starke, D. \& SMITH, D.R. 1990. Vesicular-arbuscular mycorrhizal colonization in Zea mays affected by breeding for resistnce to fungal pathogens. Can. J. Bot. 68: 1039-1044.

Traquair, J.A. \& Berch, S.M. 1988. Colonization of peach rootstocks by indigenous vesicular-arbuscular mycorrhizal (VAM) fungi. Can. J. Pl. Sci. 68: 893-898.

VIERHEILIG, H. \& OCAMPO, J.A. 1991. Susceptibility and effectiveness of vesicular-arbuscular mycorrhizae in wheat cultivars under different growing conditions. Biol. Fertil. Soils 1: 290-294.

\section{Manuscript received July 1992}

\section{Mauritz Vestberg}

Agricultural Research Centre of Finland

Laukaa Research and Elite Plant Unit

SF-41340 Laukaa, Finland 


\title{
SELOSTUS
}

\section{Vesikkeli-arbuskeli mykorritsasieniymppäyksen vaikutus kymmenen mansikkalajikkeen kasvuun ja mykorritsainfektioon}

\author{
MAURITZ Vestberg
}

Maatalouden tutkimuskeskus

VA-mykorritsasieniymppäyksen vaikutusta kymmeneen Suomessa viljeltåväăn mansikkalajikkeeseen tutkittiin astiakokeessa. Kaikkien lajikkeiden taimet olivat MTTK:n Laukaan tutkimus- ja valiotaimiasemalla tuotettuja mikrolisăttyjä pikkutaimia. Kasvualustana käytettiin luujauholla $\left(2 \mathrm{~g} \mathrm{l}^{-1}\right)$ lannoitettua steriiliä hiekkaa. Taimille annettiin myős kerran viikossa fosforivapaata Hewittin ravinneliuosta. Koe perustettiin 27.-28. toukokuuta 1990 ja se kesti 91 vuorokautta. Lajikkeet jaettiin aikaisiin ('Jonsok', 'Zefyr', 'Kristina' ja 'Mari'), myöhäisiin ('Bounty', 'Hiku' ja 'Senga Sengana') ja erikoislajikkeisiin ('Ostara', 'Alaskan pioneeri' ja 'Minja'). Sienikantojen lukumäärä oli kuusi, viisi suomalaista ja yksi ulkomainen. Eri lajikkeille laskettiin myös mykorritsariippuvaisuusindeksi (MRI), joka saatiin jakamalla ympätyn taimen kuivapaino ymppăămăttömăn taimen kuivapainolla ja kertomalla tulos sadalla.
Vallitsevissa olosuhteissa kaikki tutkitut mansikkalajikkeet hyötyivăt VAM-ymppäyksestä. Kolme sienikantaa, Glomus macrocarpum Suomesta, G. mosseae Englannista ja mäărittämătön Glomus-laji V4 Suomesta, olivat hyvin tehokkaita ja lisäsivät merkittävästi mansikalla sekä verson kasvua että rönsyjonojen ja rönsytaimien tuotantoa. Lajikkeiden välisiä eroja ei mainittavasti ollut. 'Jonsok' oli keskimäärin eniten riippuvainen mykorritsaymppäyksestä $(\mathrm{MRI}=648)$ ja 'Ostara' văhiten $(\mathrm{MRI}=269)$. Ymppäyksen seurauksena aikaisilla lajikkeilla oli keskimäärin korkeampi juuriston prosentuaalinen mykorritsainfektio kuin myöhäisillä lajikkeilla. VAM-sienet muodostivat myős itiōită runsaammin aikaisissa ja erikoislajikkeissa kuin myöhäisissă lajikkeissa. Useimmilla lajikkeilla juuriston mykorritsasienen prosentuaalinen runsaus korreloi sienen aiheuttaman verson kasvunlisäyksen kanssa, mutta rönsyntuotannon kanssa oli merkitsevăä korrelaatiota harvoissa tapauksissa. 